\title{
Potential Macrophytes for Nitrogen Removal from Domestic Wastewater in Horizontal Subsurface Flow Constructed Wetlands in Tanzania
}

\author{
Haule A.T ${ }^{1, *}$, Pratap H.B ${ }^{2}$, Katima, H.J.Y ${ }^{3}$, Mugittu $\mathrm{K}^{1}$ and Mbwette, T.S.A ${ }^{4}$ \\ ${ }^{1}$ Ifakara Health Institute, P.O Box 74, Bagamoyo, Tanzania \\ ${ }^{2}$ University of Dar es Salaam, College of Natural Sciences P.O Box 35091, Dar es Salaam \\ ${ }^{3}$ College of Engineering and Technology, University of Dar es Salaam P.O Box 35091, Dar es Salaam \\ ${ }^{4}$ Open University of Tanzania (OUT), P.O Box Dar es Salaam, Tanzania
}

\begin{abstract}
The role of six indigenous macrophytes (Cypreus grandis, C. dubis, Kyllinga erectus, Phragmites mauritianus, Typha domingensis and T. capensis) was investigated for nitrogen removal in horizontal subsurface flow constructed wetlands at the University of Dar es Salaam in Tanzania receiving waste stabilization ponds effluent. Seven horizontal subsurface flow constructed wetlands were fed with the same source of domestic wastewater, where six of them were planted with a monoculture macrophytic species while the seventh was not planted and it acted as a control cell. On alternatedays' basis for twenty eight weeks both the influent and effluent water samples from each cell were collected and sent to the laboratory for ammonia-N, nitrate-N and Total Kjeldahl-N analysis. Nitrogen bioaccumulation and plant biomasses were analyzed during the transplanting time, after ten weeks and after flowering. Temperature, $\mathrm{pH}$ and plant heights were determined in situ. Results show that overall nitrogen removal was through denitrification where K.erectus performed better (75.59\%) than the rest.Since P.mauritianus $(74.37 \%$ )established well and had the longest growing period after harvest useso therefore it was selected as the best macrophyte. More research needs to be done prior to making a final decision on the use of any of these macrophytes for nitrogen removal depending on the weather and soils of the specific area.
\end{abstract}

Keywords: Macrophytes, horizontal subsurface flow constructed wetlands, nitrogen, wastewater.

\section{INTRODUCTION}

Nitrogen removal from wastewater is crucial in Tanzania as well as in many developing countries in order to avoid polluting the receiving water bodies. A vivid example of this is what happened in Lake Victoria [1]. The lake was heavily infested with water hyacinth (Eichhornia crassipes) as a result of receiving untreated wastewater from urban centersand non points source such as farms and mines around the lake. Not only urban centersaround Lake Victoria, but also villages and industries in Tanzania lack wastewater treatment facilities [2].

Although nitrogen is an essential nutrient for plant growth, excessive concentrations can be detrimental to lake and stream water quality resulting in algal blooms, decreased light penetration, loss of dissolved oxygen and ultimately, eutrophication of receiving water bodies. Nitrogen is mainly accrued from municipal and domestic wastewater, urban water run -off, agriculture drainage and industries effluents [3]. In wastewater, nitrogen is present in both organic and inorganic forms. Ammonia nitrogen is undesirable for

*Address correspondence to this author at the Ifakara Health Institute, P.O Box 74, Bagamoyo, Tanzania; Tel: +255232440064: Fax: 1255232440064: E-mails: athanashaule@gmail.com, ahaule@ihi.or.tz discharge to receiving water bodies due to its toxicity to fish and high dissolved oxygen demand (DOD) which contributes to the eutrophication of fresh water bodies. Nitrites and nitrates both are undesirable for discharge to ground water because of their toxicity to humans especially infants [4]. The presence of more than $45 \mathrm{mg} / \mathrm{L}$ of nitrates $(10 \mathrm{mg} / \mathrm{L}$ $\mathrm{NO}_{3}-\mathrm{N}$ ) the maximum concentration level (MCL) for drinking water may cause methemoglobinemia (blue-baby syndrome). The disease is generally confined to infants less than three months old but may affect children up to age six [5].

Aquatic plants can be utilized in three different kinds of systems for the removal of nitrogen and/or heavy metals. The lagoons with floating plants such as water hyacinth and duckweed have been investigated since the seventies [4] and are currently in use at a large scale for the treatment of municipal wastewater in Asia. The constructed wetlands with emerging plants such as the reeds and bulrush have been investigated and applied more recently [3]. These structures are becoming an increasingly common method for the treatment of all forms of water pollution including confined animal wastewater, cropland run-off, urban storm water, septic tank effluent, municipal wastewater effluent, acid mine drainage, industrial process water and landfill leachate $[2,6]$. Most of them are used for tertiary municipal wastewater treatment (nutrient and feacal coliform reduction) with a 


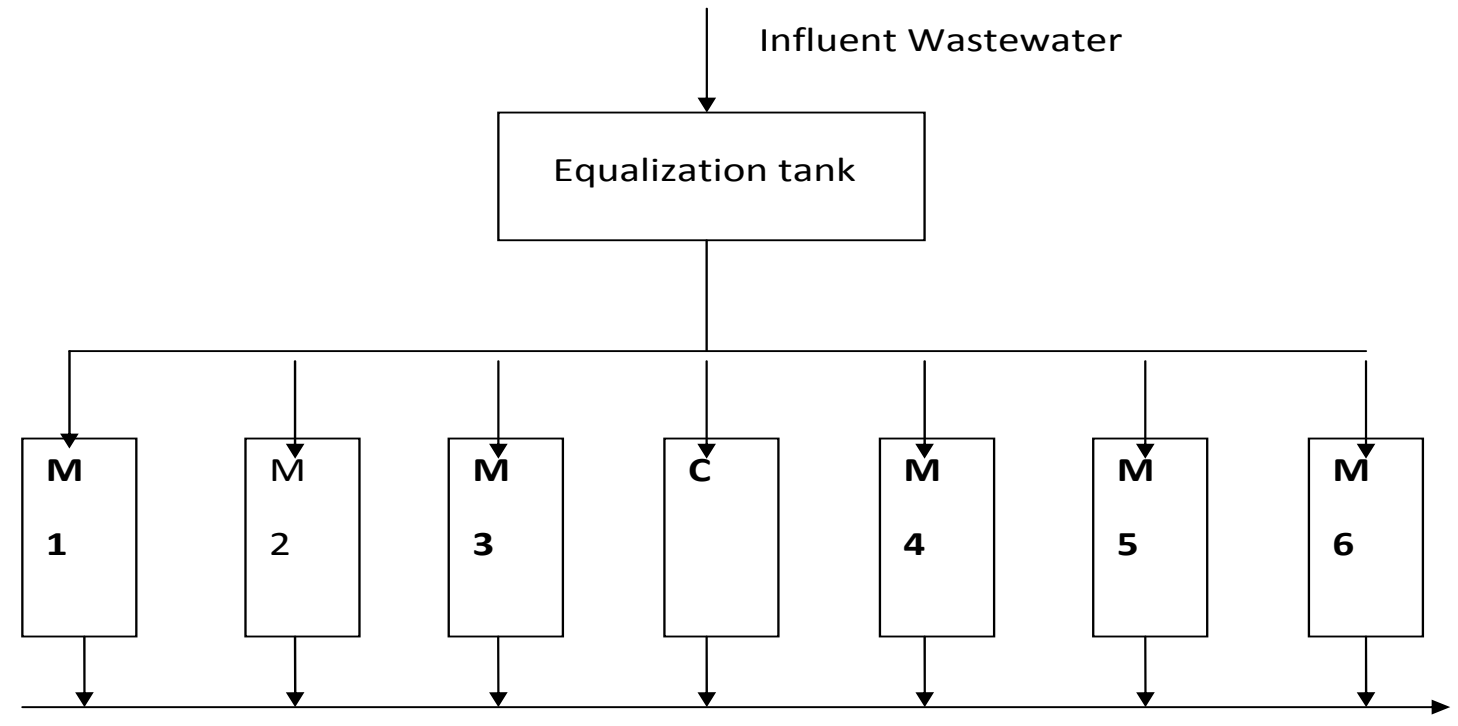

\section{Effluent to receiving water bodies}

Fig. (1). HSSFCW receiving last maturation pond wastewater at the University of Dar es Salaam where M1 $=T$. domingensis, M2=C. grandis, $\mathrm{M} 3=K$. erectus, $\mathrm{C}=$ control, $\mathrm{M} 4=P$. mauritianus, $\mathrm{M} 5=C$. dubius, $\mathrm{M} 6=T$. capensis .

large number also in a place for secondary wastewater treatment (solids and biological oxygen demand (BOD) reduction [7]. Of the two constructed wetlands technologies, horizontal subsurface flow is favoredto surface flow, because it offers aesthetic wastewater treatment devoid of flies and odour [8].

Macrophytes (water plants) are an indispensable component of these wetland ecosystems [9]. Macrophytes, soil substrate and water, are the main components of the wetlands system, and that the substrate is non-soil and is saturated with water or covered by shallow water sometimes during the growing season of each year [10]. Thus the presence or absence of macrophytes is one of the characteristics used to define a wetland, and there are three types of macrophytes found in wetlands; namely free floating, submerged and emergent macrophytes; named after how the macrophytes are anchored and seen on the water surface [5, 6]. Macrophytes provide surface area for microbes to attach and grow [11]. The numbers and kind of microorganisms on or near root surface are highly variable depending on the macrophytes species and soil nutrient water status [12]. Microbes are the ones that do the real job of wastewater treatment by decomposing the dead organic matter releasing the nutrients and successively using them for growth [13], as a result the harmful chemicals are rendered harmless [6]. Macrophytes such as Phragmitesmauritianus, Typhadomingensis, T.capensis, Cyperus grandis, C. dubius and Kyllinga erectus have been used in horizontal subsurface flow constructed wetlands in various tropical countries including Colombia, Brazil India Kenya and Uganda for nitrogen removal [5-7]. However, the potential of these indigenous plants in wastewater treatment in Tanzania has not been investigated. Therefore, this study was aimed at identifying potential indigenous emergent macrophytes to be used on a large-scale for nitrogen removal in horizontal subsurface flow constructed wetlands in Tanzania after many isolated communities, wildlife lodges, schools, colleges, etc, started to embrace this technology to solve their domestic wastewaters.

\section{MATERIALS AND METHODS}

The study was conducted at the University of Dar es salaam main campus waste stabilization ponds (WSP) area which receives all domestic wastewater from the laboratories, offices, workshops, dispensary, dormitories and staff quarters. Seven parallel horizontal subsurface flow constructed wetland cells each $(1 \mathrm{~m} \times 0.7 \mathrm{~m} \times 0.4 \mathrm{~m})$ filled with the same soil substrate (gravels) of the same size of 8-21 mm were constructed (Fig. 1). Six cells were planted with a single dominating indigenous macrophytes species while the seventh cell was not planted because it acted as control. All cells were supplied with influent domestic wastewater of the same quality from the last maturation pond of the waste stabilization pond system. Detention time was 8 hours and flow rate was $0.172 \mathrm{~m}^{3}$ per day. Twenty-five seedlings per cell of each species were planted where the shoot part of the plant was kept above the soil surface while the rhizome part was buried below the surface and about $5 \mathrm{~cm}$ inside the wastewater. Other phenomenons took place as they do in natural environment.

Population/density of Macrophytes increased in numbers and heights in relation to time and nutrient availability.Using a tape measureplant heights (in centimeters) were determined weekly. Influent and effluent water samples were collected in plastic bottles and transported in cooler boxes kept at $4^{\circ} \mathrm{C}$ to the laboratory to be analyzed for ammonia $\left(\mathrm{NH}_{4}-\mathrm{N}\right)$ Total Kjeldahl nitrogen $(\mathrm{TKN})$ and nitrate $\left(\mathrm{NO}_{3}-\mathrm{N}\right)$. A portable $\mathrm{pH}$ meter Metrohm model 704 was used to determine in situ both the temperature and $\mathrm{pH}$ of the influent and effluent from each cell. Wastewater flow rate was also determined in situ. Each macrophyte was analyzed for $\mathrm{N}$ bioaccumulations in different plant parts i.e. root, stem and shoot (leaves). The shoots, stems and roots (rhizomes) of the macrophytes were dried at $105^{\circ} \mathrm{C}$, ground with washed sand and measured for $\mathrm{N}$ content using the method explained in APHA [12]. For each macrophytic species the specific growth rate as percentage increase in fresh weight was calculated as $\mu=1001$ n $\left(\mathrm{w}_{\mathrm{t}} / \mathrm{w}_{0}\right) \mathrm{t}$ where $\mu$ is the specific growth rate, $\mathrm{w}_{\mathrm{t}}$ is biomass at 


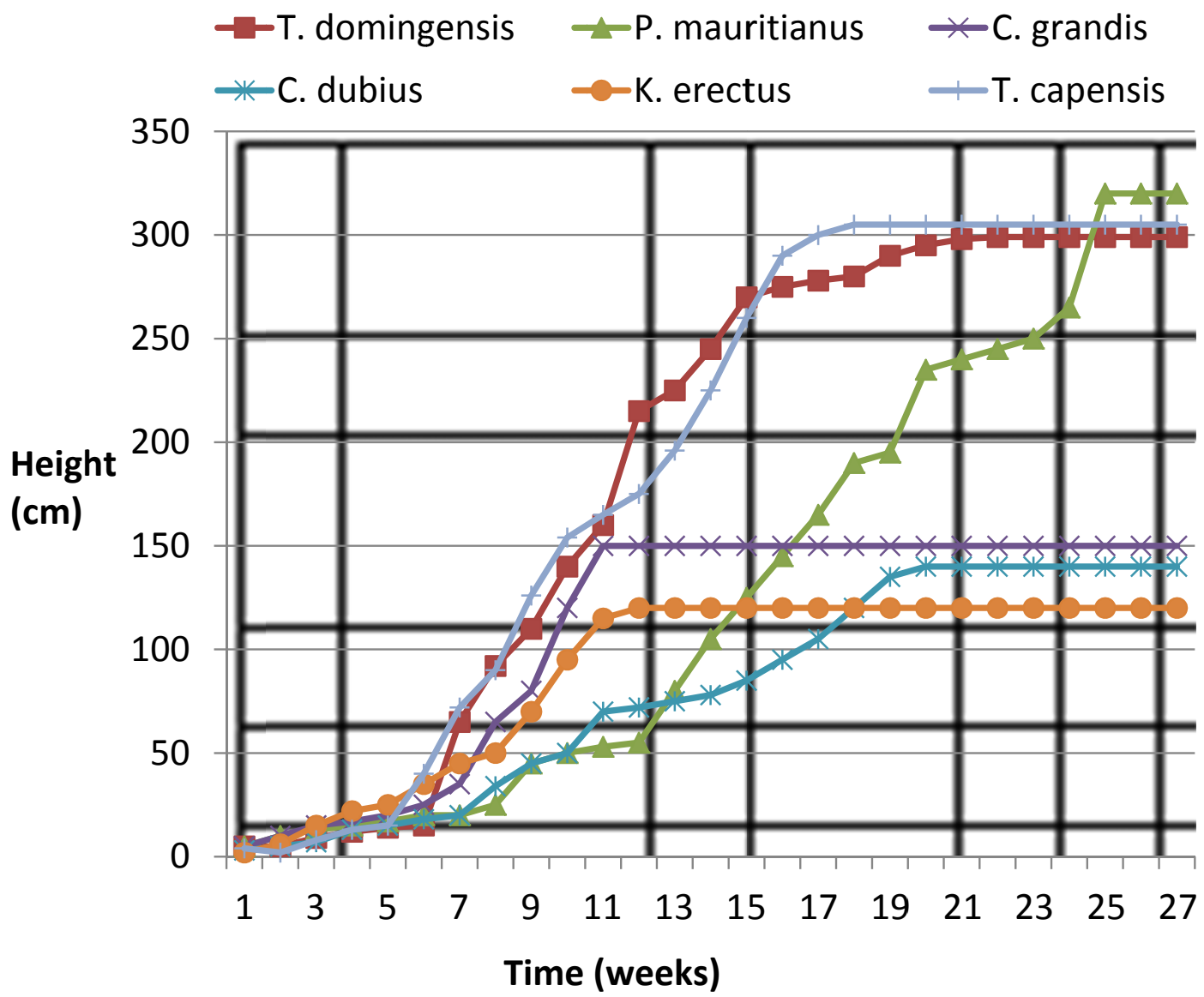

Fig. (2). Macrophytes growth pattern in weeks and height in $\mathrm{cm}$.

time $\mathrm{t}$ and $\mathrm{w}_{0}$ is the initial biomass. Data were analyzed using Kruskal-Wallis Non Parametric ANOVA Tests and Dunns Multiple Comparison Tests. Other statistical method used was Tukey-Kramer.

The efficiency of each species to remove nitrogen from wastewater was determined by the ability to remove nitrate $\mathrm{N}$ and ammonia $\mathrm{N}$ by up taking or other processes that influence the loss of $\mathrm{N}$ from the wetlands by means such as volatilization and denitrification.

\section{Temperature}

The maximum and minimum influent temperature ranged between $34.2^{\circ} \mathrm{C}$ and $25^{\circ} \mathrm{C}$. All wetlands displayed the same pattern of temperature hence there was no significant temperature difference $(p>0.001)$ among the different wetlands dominated by different macrophytes. Temperature variation was minimum as the average effluent temperature for the different wetland cells was $27.36 \pm 1.0^{\circ} \mathrm{C}$ and the influent was at $28.18 \pm 2.31^{\circ} \mathrm{C}$.

\section{pH}

The effluent $\mathrm{pH}$ from the different wetland cells dominated by monoculture macrophytes ranged between 6.87 and 9.85 while the average influent $\mathrm{pH}$ was $9.71 \pm 0.33$. Kruskal Wallis nonparametric ANOVA test followed by Dunns multiple comparisons Tests showed that there was a very significant difference $(\mathrm{p}<0.001)$ in $\mathrm{pH}$ between the influent and effluent from the different HSSFCW dominated by single macrophytes. Control effluent showed the same result as that of the influent. However there was no significant difference in $\mathrm{pH}(\mathrm{p}>0.05)$ among the macrophytes except for $C$. grandis because it could not establish well in the wetlands.

\section{RESULTS}

\section{Macrophytes Growth Pattern}

Most macrophytes grew taller at the influent inlet and shorter at the effluent outlet along nutrient gradient.T. domingensis and $T$. capensis exhibited exponential growth from week 2 to 17 and achieved the maximum height of between $125 \mathrm{~cm}$ and $300 \mathrm{~cm}$ for $K$. erectus and $P$. mauritianus, respectively. Phragmites mauritianus showed longer exponential growth phase from week 2 to 25 while $K$. erectus showed the shortest exponential growth phase starting from the week 2 to 12 (Fig. 2).

Three growth phases were observed where from planting to week two was a lag phase, week two to week seventeen a growth phase and beyond that a stagnant phase.

\section{Ammonia-N, Nitrate-N, TKN and Organic-N Removal}

Ammonia inflow averaged $3.18 \pm 0.32 \mathrm{mg} / \mathrm{l}$ and the $\mathrm{NH}_{3}-$ $\mathrm{N}$ remaining average was $1.05 \pm 0.46 \mathrm{mg} / \mathrm{l}$ equivalent to $67 \%$ removal. The mean influent nitrate-N concentration was 5.43 $\mathrm{mg} / 1$ and the effluent averaged $0.7 \mathrm{mg} / \mathrm{l}$ which was equivalent 


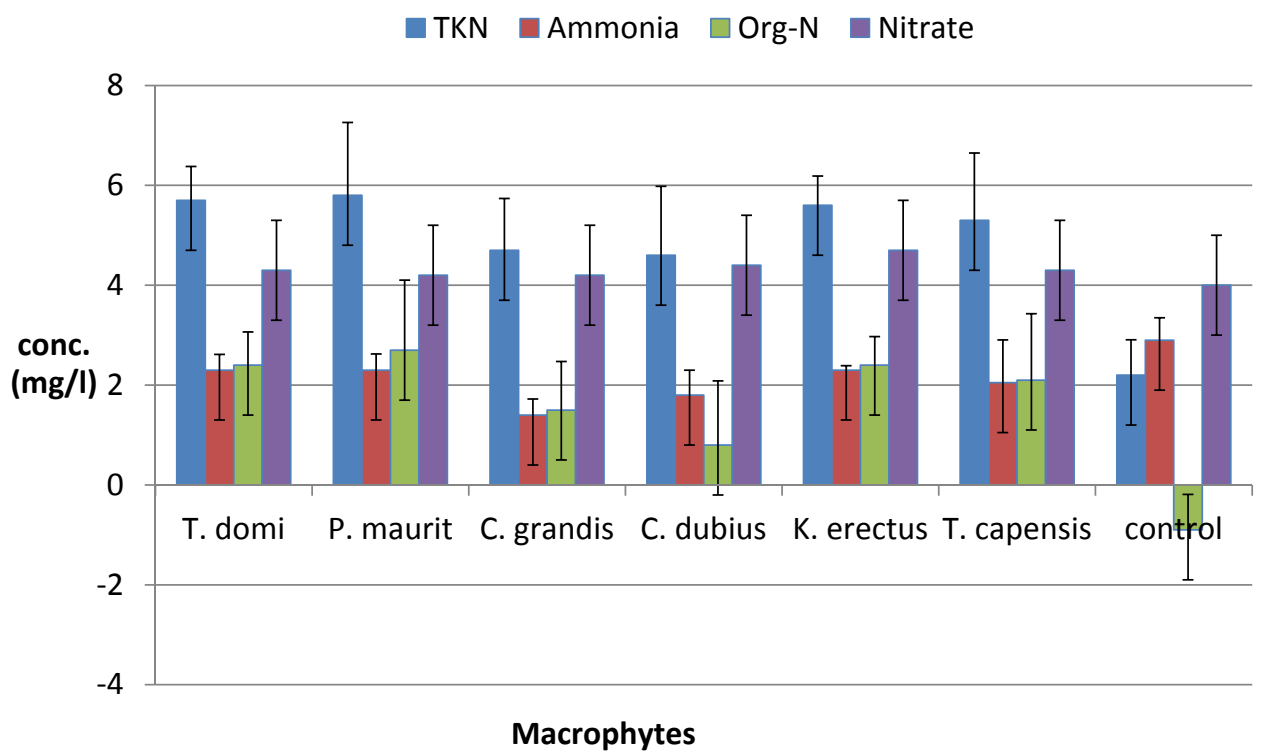

Fig (3). Nitrogen removal (mg/l) by macrophytes in various forms in constructed wetlands.

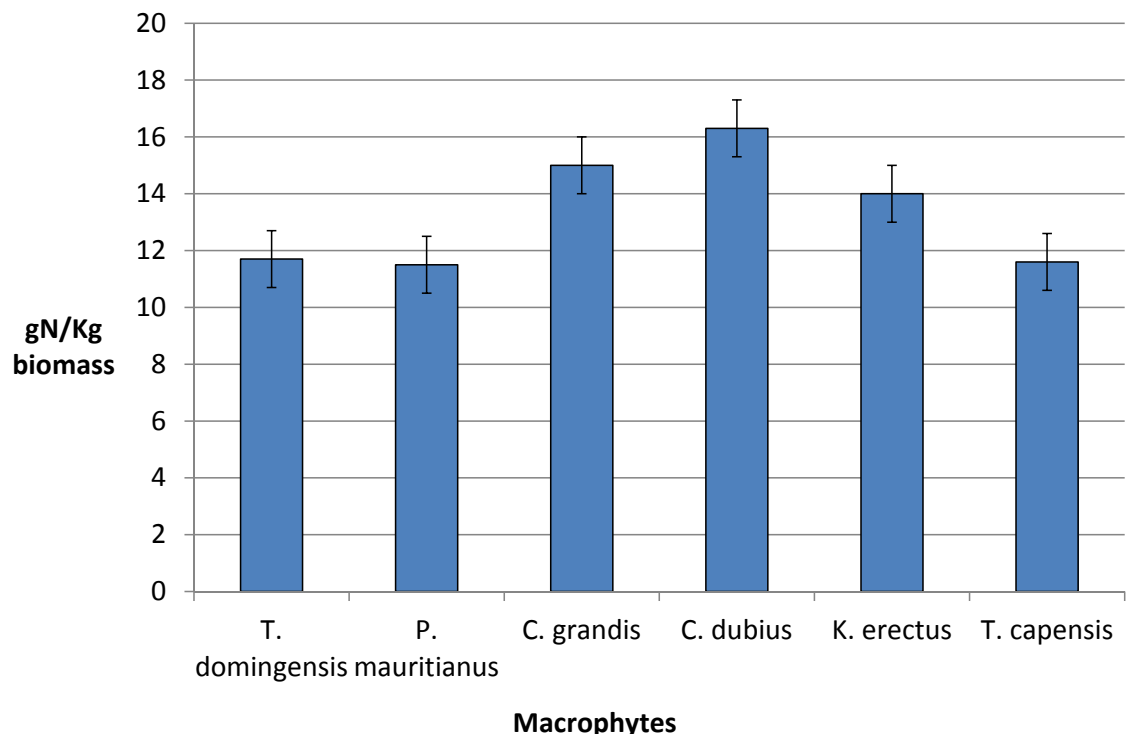

Fig. (4). Specific N-bioaccumulated by different macrophytes.

to $85.6 \%$ removal. Mean Total Kjeldahl nitrogen (TKN) influent was $8.06 \mathrm{mg} / \mathrm{l}$ and its effluent averaged $3.49 \mathrm{mg} / \mathrm{l}$ equivalent to $56.6 \%$ removal. Average influent Org-N was $4.88 \mathrm{mg} / 1$ and effluent was $2.33 \mathrm{mg} / 1$ equivalent to $52.1 \%$ removal (Fig. 3). There was a significant difference in TKN removal between the control wetland and the macrophytes dominated wetlands (Tukey-Kramer q>4.25, $\mathrm{p}<0.001$ ). However, there was no significant difference $(\mathrm{p}>0.05)$ in Org-N removal between the control wetland and the macrophytes dominated wetlands (Kruskal-Wallis Statistic $\mathrm{KW}=$ 68.441).

There was no significant difference in TKN and nitrate-N removal among $K$. erectus, $T$. capensis, $T$. domingensis and $P$. mauritianus Furthermore, there was no significant difference in TKN removal between the Cyperus species. How- ever, there was a significant difference in TKN removal between the Cyperus species and the rest. Moreover, there was a significant difference in ammonia- $\mathrm{N}$ removal between the control and the planted wetlands. The control wetland performed better in ammonia- $\mathrm{N}$ removal but poorly in organic$\mathrm{N}$ removal.

\section{Specific N- Bioaccumulation by Different Macrophytes}

All macrophytes showed the same trend in $\mathrm{N}$ bioaccumulation. Immature plants being in the growth phase (exponential growth phase) bioaccumulated more $\mathrm{N}$ than mature plants of the same species. The longer the growth phase of the macrophyte, the more $\mathrm{N}$ bioaccumulation (Fig. 4).

Cyperus dubius bioaccumulated more $\mathrm{N}$ per kilogram biomass in the HSSFCW, followed by $C$. grandis, and $K$. 


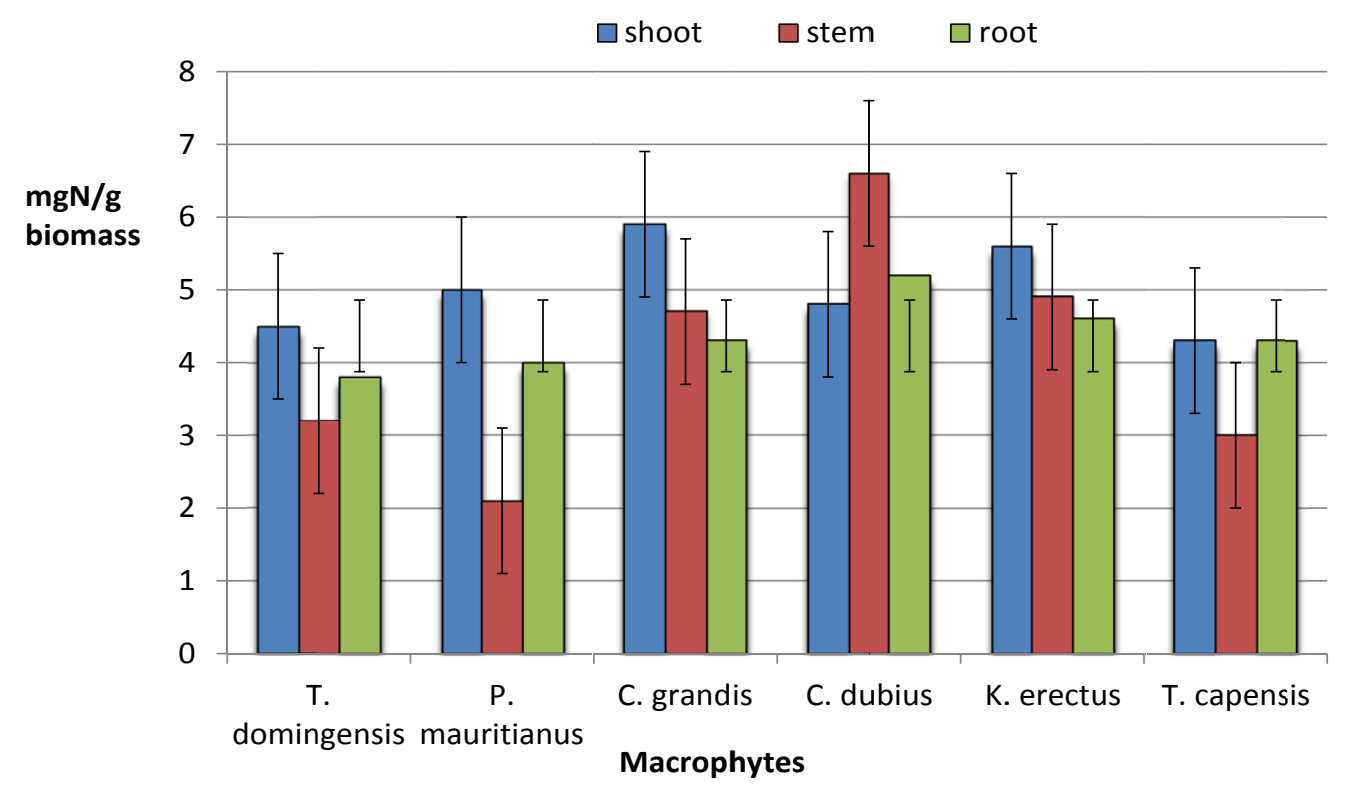

Fig. (5). N-bioaccumulation by different plant parts.

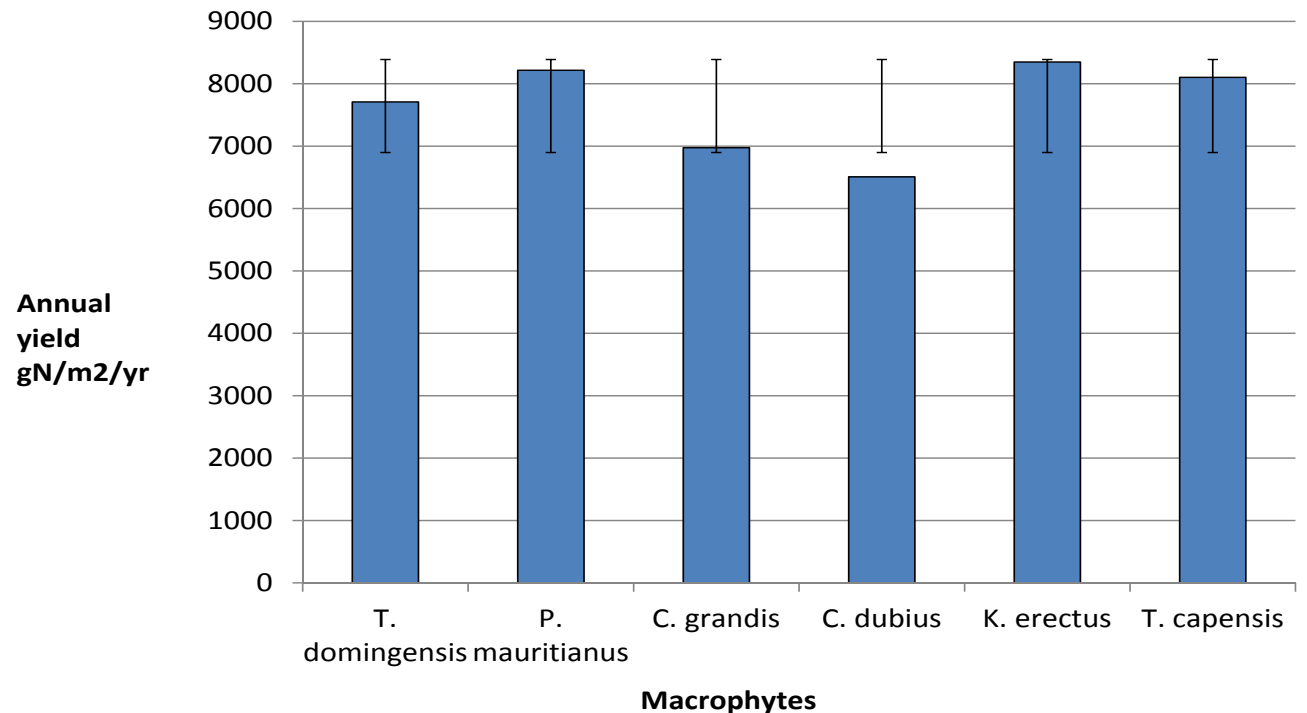

Fig. (6). Overall $\mathrm{N}$ removal through bioaccumulation by indigenous macrophytes from domestic wastewater in HSSFCW.

erectus. The remaining three macrophytes (T. domingensis, $T$. capensis and $P$. mauritianus) showed no significant difference ( $\mathrm{p}>0.001)$ in N-bioaccumulation (Fig. 4).

\section{N- bioaccumulation by Different Plant Parts}

$\mathrm{N}$ - bioaccumulation by different plant parts is shown in Fig. (5) below. There was a significant difference in $\mathrm{N}$ bioaccumulation among the different macrophytes and among plant parts of the same species and of different species.

Shoots of all macrophtes except that of C. dubius bioaccumulated more $\mathrm{N}$ followed by roots and lastly stems. However, stems of $\mathrm{K}$. erectus bioaccumulated more $\mathrm{N}$ than its roots.

\section{Overall N Bioaccumulation by Indigenous Macrophytes Planted in HSSFCW for N-removal from Domestic Wastewater}

The overall $\mathrm{N}$-bioaccumulation from domestic wastewater in the HSSFCW is shown in Fig. (6) above
There was no significant difference in overall $\mathrm{N}$ removal through bioaccumulation among the macrophytes. However, $T$. capensis, $T$. domingensis and $P$. mauritianus performed better than the Cyperus species of $C$. dubius and C. grandis.

\section{Overall N Removal by Indigenous Macrophytes (In Per- centage) from Domestic Wastewater in HSSFCW}

The overall $\mathrm{N}$ removal from domestic wastewater by indigenous macrophytes HSSFCW through plant uptake, effluent flow to receiving water bodies and denitrification processes within the wetland is shown in Fig. (6) below.

Denitrification is the major process responsible for removal of nitrogen in constructed wetlands which is followed by effluent and lastly plant uptake (Fig. 7). Annual N loading and removal areshown in Fig. (8) below. Since influent $\mathrm{N}$ concentration was the same for all $\mathrm{N}$ species to all the macrophytes, there was significant $\mathrm{N}$ removal from the different macrophytes (Tukey-Kramer $\mathrm{q}>4.25, \mathrm{p}<0.001$ ). 


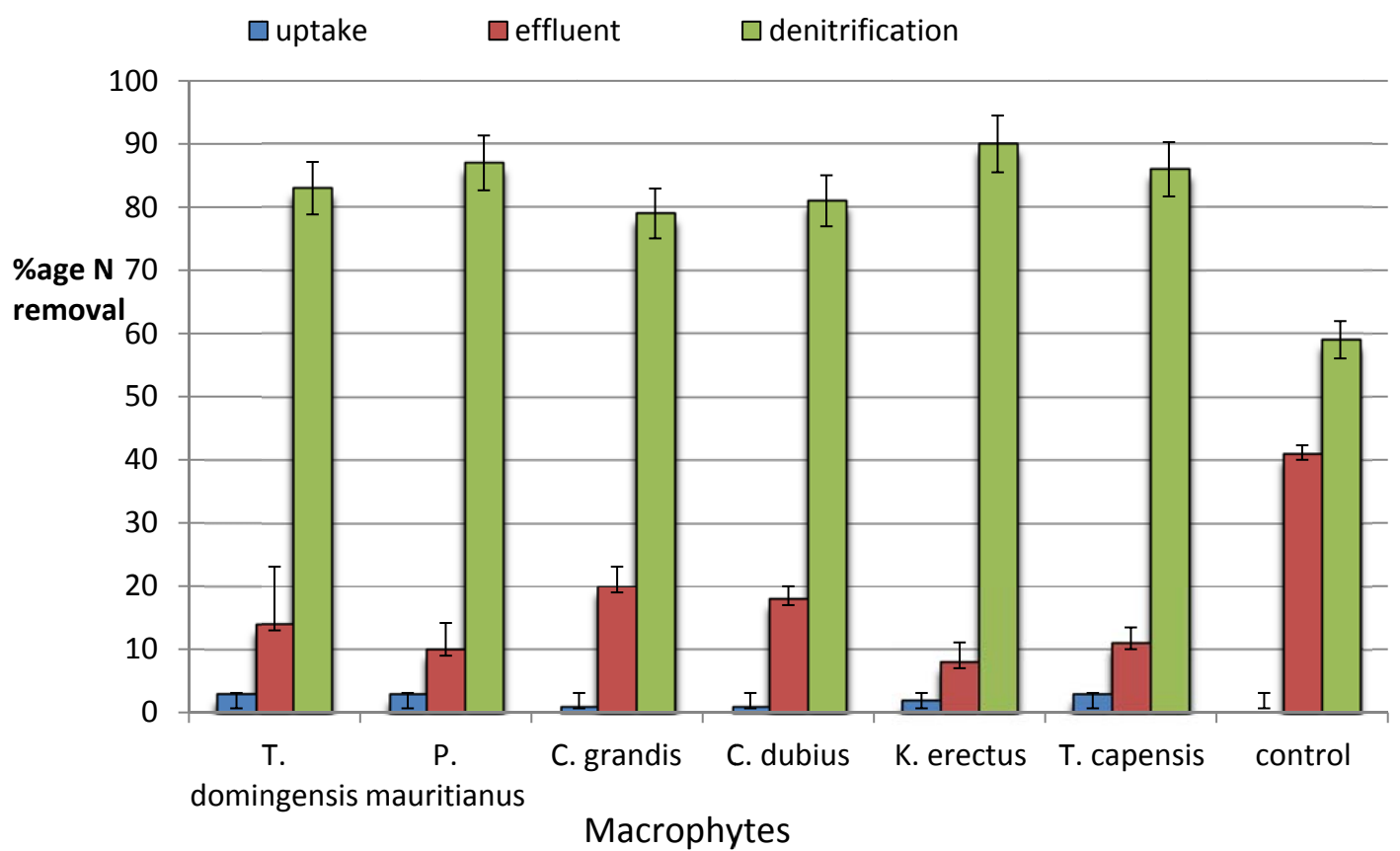

Fig. (7). Overall $\mathrm{N}$ removal by indigenous macrophytes (in percentage) from domestic wastewater in HSSFCW.

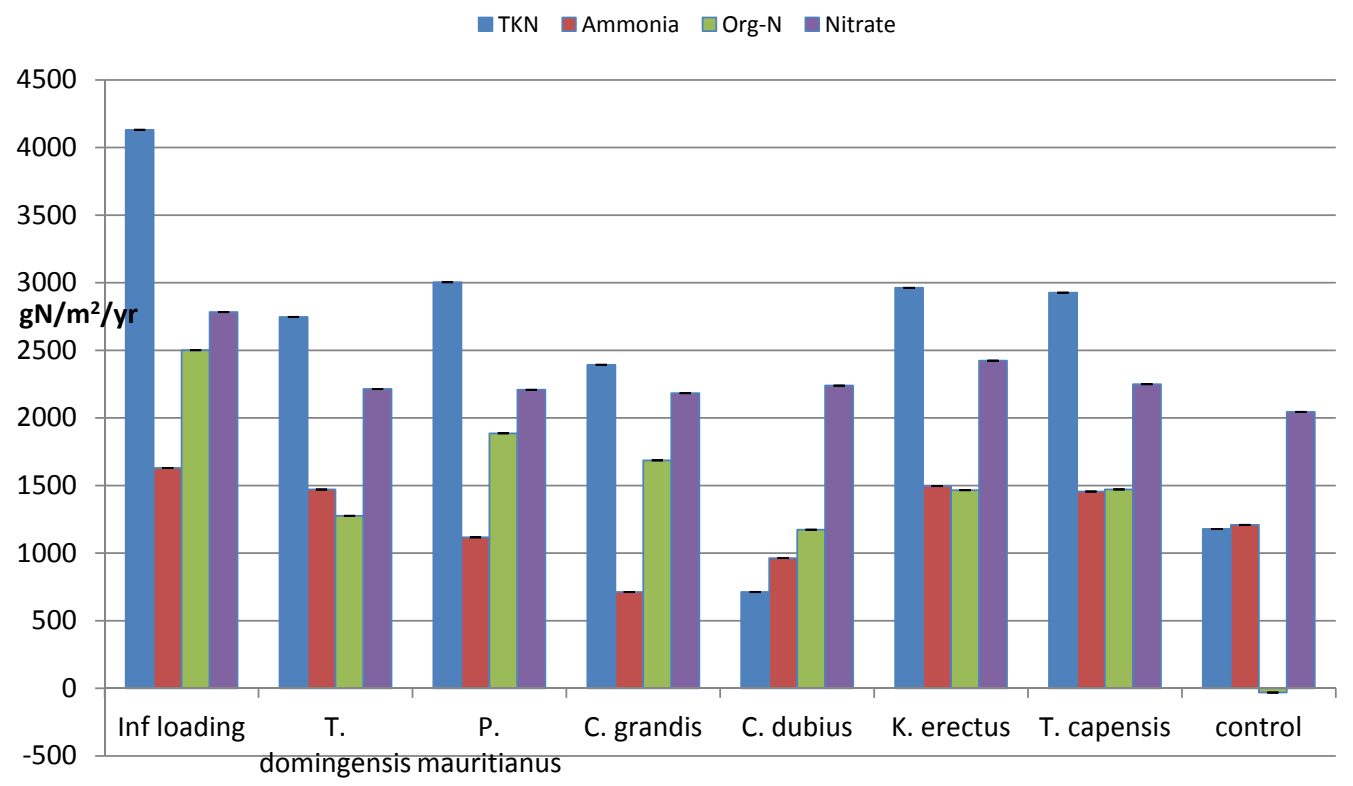

\section{Macrophytes}

Fig. (8). The average annual $\mathrm{N}$ loading and removal by different indigenous macrophytes planted in HSSFCW.

However, there was no significant difference $(\mathrm{p}>0.05)$ in Org-N removal between the control wetland and the macrophytes dominated wetlands (Kruskal-Wallis Statistic KW = 68.441).

\section{DISCUSSION}

Temperature and $\mathrm{pH}$ influence plant growth [14] as most aquatic lives have a very narrow range of tolerance within which they can survive. Temperature influences the rate of photosynthesis, metabolism and the sensitivity of macrophytes to toxic wastes and diseases [1]. In this study all six plant spp. performed equally reasonably well at these ranges on temperatures and $\mathrm{pH}$. In early stages of the plants growth, $\mathrm{pH}$ in all wetlands dropped steeply down to a point when it started to go up again. The elevated influent $\mathrm{pH}$ during the day was due to algal photosynthetic activity in the maturation pond of the WSP system, however inside the HSSFCW due to lack of light intensity where the carbon dioxide $\left(\mathrm{CO}_{2}\right)$ was not absorbed for photosynthetic activity led to low $\mathrm{pH}$. Respiration by different microorganisms in soil releases $\mathrm{CO}_{2}$ which dissolves in the water medium forming weak acids which lower the $\mathrm{pH}$ [13]. Acid water increases the solubility 
of some metals making them biologicallymore available. Results from this study show the same trend as those found by other researchers [15-20].

Nitrogen removal was dependent on the developmental stage of the macrophytes. During the exponential growth phase both ammonia-N and nitrate- $\mathrm{N}$ concentrations decreased rapidly in the planted wetlands. This was due to both plant uptake and denitrification [21]. However, plant uptake is only between $0-5 \%$ [22]. In HSSFCW, ammonia-N is mainly lost through nitrification to nitrate- $\mathrm{N}$ [9] and then denitrification of nitrate- $\mathrm{N}$ to nitrogenous gases [14]. The loss of nitrate- $\mathrm{N}$ in the unplanted control wetland is also mainly due to denitrification [10]. Overall nitrogen removal was highest by the $K$. erectus followed by $P$. mauritianus, $T$. capensis and $T$. domingensis. This was mainly due to $K$. erectus forming a dense network of roots compared to other macrophytes. Dense root network means pumping more oxygen and hence more nitrification [11-13]. Denitrification then takes place which eliminates nitrogenous gases in large quantities [4]. Phragmites mauritianus, T. domingensis and $T$. capensis followed in overall nitrogen removal because they also form large extensive root biomasses [13]. However, specific N-bioaccumulation was the highest in $C$. grandis and $C$. dubius. This is because these species had a high plant growth rate which is an indication of how fast a macrophyte bioaccumulates $\mathrm{N}$ in a specified time. Unfortunately $C$. grandis could not establish itself well in the HSSFCW requiring frequent replanting compared to $C$. $d u$ bius which was quick in establishing itself in the newly constructed HSSFCW. Both C. grandis and C. dubius had shortest growing period together with $K$. erectus.

Nitrogen bioaccumulation was highest in the immature macrophytes because these plants are in the growing stage, which uptake nitrogen for growth purposes $[2,8]$. Flowered macrophytes followed in $\mathrm{N}$ bioaccumulation but this test was stopped right after flowering when there was no more increase in plant height. Senescence starts after flowering involving remobilization and loss of $\mathrm{N}$ back into the wetlands again [10]. Another macrophyte species that adapted quickly in the HSSFCW and competed well with the two Typha species and $K$. erectus was $P$. mauritianus. Phragmites mauritianus showed second highest overall $\mathrm{N}$ removal after $K$. erectus because it has the longest growing period and has an extensive network of roots too $[6,11]$. For efficient organic$\mathrm{N}$ removal, aerobic conditions are needed to accelerate both mineralization and nitrification as N-removal is achieved at high and low redox micro sites in juxta position as in deep microbial films with aerobic surfaces $[20,23]$. The leakiness of the roots for oxygen varies with plant species [14]. As in water hyacinth (E. crassipes), wetland macrophytes productivity is a function of three factors; air temperature, nutrients availability and plant density. This was also true forother plants as observed in the previous studies [12]. Thus productivities and removal efficiencies varied depending on the biology of individual species which include plant biomass ability to pump in oxygen and to prove condition that favorsnitrification and denitrification of nitrogen [24].

Tukey Kramer multiple comparison tests done between the control and the planted wetlands showed that there was a significant difference $(p>0.05)$ in ammonia removal between the control and the planted wetlands and among the macrophytes. Among the macrophytes, K. erectus, T. domingensis, $T$. capensis and $P$. mauritianus showed better performances. Thus the plant age, growth rate and standing crop (biomass) influence the potential rate of nitrogen bioaccumulation by aquatic plants per unit area [23-25]. Likewise, the shoot system bioaccumulated more $\mathrm{N}$ than other parts except for $C$. dubius, because this is the site where photosynthesis takes place [26]. These results are in line with other researchers $[23,24]$.

\section{CONCLUSION}

Macrophytes that display shorter exponential growth phase e.g. K. erectus if used for $\mathrm{N}$ removal from constructed wetland have a disadvantage of frequent harvesting, which is labourious and time consuming. Such macrophytes should not be considered as potential for $\mathrm{N}$ removal from constructed wetlands even if they are better in $\mathrm{N}$ update unless after-harvest-use such as livestock feed or other use is available. According to this study it can be concluded that macrophytes that establish well in constructed wetlands and that display longer growing periods, have high biomass turnover per area. Thus T. capensis, $T$. domingesiss and $P$. mauritianus are potential for nitrogen removal from domestic wastewater in horizontal subsurface constructed wetlands because they have longer exponential growth phase and have after-harvest-use in construction and craft industries. It should also be noted that actual pollution removal rates depend on the quality of the influent, the aquatic treatment volume, the surface area to volume ratio, the ratio of wetlands surface area to watershed area and most important is the macrophytes' species. Additionally influent flow paths through the wetland and longer detention times within the wetlands are expected to improve removal rates.

\section{RECOMMENDATIONS}

Detailed assessment is needed to determine if the HSSFCW should continue to receive Secondary WSP effluent or treat primary facultative pond effluent so as to minimize area requirement needed by the maturation ponds. Collection of information for this assessment should be on a controlled subsurface flow constructed wetland for a longer period. More investigation is needed to study the relationship between the detention time, soil substrate and macrophytes species. Other dominant emergent indigenous macrophytes species in other geographical areas in the whole country need to be investigated. A database of indigenous wetland macrophytes potential for domestic wastewater treatment needs to be established.

\section{CONFLICT OF INTEREST}

The authors confirm that this article content has no conflicts of interest.

\section{ACKNOWLEDGEMENT}

This research work was financed by the Danish government through DANIDA- ENRECA to whom the authors are grateful. It was a collaboration project between the Royal Danish School of Pharmacy and the Technical University of 
Copenhagen Denmark and the Faculties of Science and Engineering of the University of Dar es Salaam Tanzania under the WSP and CW Research Project. I also thank the Ifakara Health Institute (IHI), Bagamoyo Branch Research Scientists for their assistance in preparing this manuscript.

\section{REFERENCES}

[1] J. M. Patrick, "Water nutrients, plant nutrients, and indicators of biological control on water hyacinth at texas field sites", J. Aquat. Plant Manag., vol 44, pp. 109-114, 2006.

[2] African Development Bank (ADB) - Tanzania Rural Water Supply and Sanitation Program II. Appraisal Report, April 2010.

[3] D. Sangeeta, and D. Savita, "Water Quality Improvement through Macrophytes: A Case Study", Asian J. Exp. Sci., vol. 21 (2), pp. 427-430, 2007.

[4] J. Safari, "Ecological and socio-economic utilization of water hyacinth (Eichhornia crassipes)", J. Appl. Sci. Environ. Manag., vol. 14 (2), pp. 43-49, 2010.

[5] J. Vymazal, "Constructed wetlands for wastewater treatment", Water, vol. 2, pp. 530-549, 2010.

[6] D. Sangeeta, "Role of Macrophytes in improving water quality of an aquatic eco-system", J. Appl. Sci. Environ. Manag., vol. 11(4), pp. 131-135, 2007.

[7] U.N. Nor Uka, and K.S. Chukwuka, "Utilization of Aquatic Macrophytes in Nigerian Freshwater Ecosystem", J. Fish. Aquat. Sci., vol. 6, pp. 490-498, 2011.

[8] S.E. Jorgensen, "Comparison of the purification efficiency of constructed wetlands in Tanzania and Denmark", In: Proceedings of the $8^{\text {th }}$ International Conference on Wetland Systems for Water Pollution Control, vol. 2, pp. 1-6, 2002.

[9] T. Y. Yeh, C. C. Chuang, and C. H. Ju, "Pollutants Transformation and Removal within Constructed Wetlands Hybrid Systems", In: Proceedings of the 4th WSEAS Int. Conf. on Heat Engineering, Transfer, Thermal Engineering and Environment, Elounda: Greece, pp. 27-33, August 21-23, 2006.

[10] C. Keffalla, and A. Grab, "Nitrogen and bacterial removal in constructed wetlands treating domestic wastewater", Desalination, vol. 185 pp. 383-389, 2005.

[11] D. Kurniadie, "Wastewater treatment using vertical subsurface flow constructed wetland in indonesia”, Am. J. Environ. Sci, vol. 7 (1), pp. 15-19, 2011

[12] P. Kuschk, A. WieXner, U. Kappelmeyer, E. WeiXbrodt, K. M. Astner, and U. Stottmeister, "Annual cycle of nitrogen removal by a pilot-scale subsurface horizontal flow in a constructed wetland under moderate climate", Water Res., vol. 37, pp. 4236-4242, 2003.

[13] E. S. Bayley, and J. K. Guimond, "Aboveground biomass and nutrient limitation in relation to river connectivity in montane floodplain marshes", Wetlands, vol. 29(4), pp. 1243-1254, 2009.
[14] A. Kasan, and F. Recknagel, "Contribution of Macrophytes to Store Nutrient in the Cox Creek Wetland System". In: Proc of University Malaysia Terengganu $10^{\text {th }}$ International Annual Symposium UMTAS, 2011: Empowering Science Technology and Innovation Towards a Better Tomorrow, UMTAS, 2011.

[15] B. L. Nyachhyon, Service Enhancement and Development of Sanitary Sewarage System in Urban and Semi-Urban Setting in Nepal, Policy Paper 23, prepared for Economic Policy Network, Ministry of Finance (MOF)/HMGN and Asian Development Bank (ADB): Nepal Resident Mission, Kathmandu, Nepal, 2006

[16] Ciria M, Solano M, and Soriano P, "Role of macrophyte typha latifolia in a constructed wetland for wastewater treatment and assessment of its potential as a biomass fuel", Biosyst. Eng., vol. 92, Issue: 4, pp. 535-544, 2005.

[17] APHA, AWWA and WEF, Standard methods for the examination of water and wastewater, $21^{\text {st }}$ ed. American Public Health Association: Washington, DC. 2005.

[18] A. I. T. Perbangkhem, and B. C. Polprasert, "Biomass production of papyrus (Cyperus papyrus) in constructed wetland treating lowstrength domestic wastewater". Bioresour. Technol, vol. 101, pp. 833-835, 2010.

[19] L. Shuwen, A. Irving, Mendelssohn, H. Chen, and H. O. William, "Does sulphate enrichment promote the expansion of Typha domingensis (cattail) in the Florida Everglades?", Freshw. Biol.,vol. 54, pp. 1909-1923, 2009.

[20] K. Song, S.H. Lee, and H. Kang, "Denitrification rates and community structure of denitrifying bacteria in newly constructed wetland", Eur. J. Soil Biol., vol. 47, 2011.

[21] C. Lee, D. T. Fletcher, and G. Sun, Review: Nitrogen removal in constructed wetland Systems. Eng. Life Sci., vol. 9, no. 1, pp. 1122,2009

[22] C. J. Varnell, S. Thawaba, and J. Van Brahana, "Constructed Wetlands for the Pre-Treatment of Drinking Water Obtained from Coal Mines", Open Environ. Eng. J., vol. 2, pp. 1-8, 2009.

[23] J. Debing, S. Baoqing, Z. Hong, and H. Jianming, "Chemical oxygen demand, nitrogen and phosphorus removal by subsurface wetlands with Phragmites vegetation in different models", Eng. Life Sci., vol.10, no. 2, pp. 177-183, 2010.

[24] J. Debing, Z. Lianbi, Y. Xiaosong, H. Jianming, Z. Mengbin, and W. Yuzhong, "COD, TN and TP Removal of Typha Wetland Vegetation of Different Structures", Polish J. Environ. Stud, vol. 18, no. 2, pp. 183-190, 2009

[25] J. Vyamazal, "Removal of nutrients in various types of constructed wetlands", Sci. Total Environ.,vol. 380, pp. 48-65, 2007.

[26] S. Enriquez, N. Marba, J. Cebrian, and C. M. Duarte, "Annual variation in leaf photosynthesis and leaf nutrient content of four Mediterranean seagrasses", Botanica Marina, vol. 47, pp. 295-306, 2004

(C) Haule et al.; Licensee Bentham Open.

This is an open access article licensed under the terms of the Creative Commons Attribution Non-Commercial License (http://creativecommons.org/licenses/by-nc/3.0/g) which permits unrestricted, non-commercial use, distribution and reproduction in any medium, provided the work is properly cited. 